\title{
Pengembangan Model Latihan Kebugaran Jasmani Berbasis Aktivitas Bermain
}

\author{
Asep Sujana Wahyuri \\ Fakultas IImu Keolahragaan \\ Universitas Negeri Padang
}

\begin{abstract}
Abstrak
Para ahli dan pakar telah mengemukan berbagai pendapat mengenai hakekat bermain antara lain:

"Bermain adalah sesuatu yang membantu anak mencapai perkembangan yang utuh baik fisik, intelektual, sosial, moral, emosional.Bermain adalah prasyarat untuk keterampilan masa yang akan datang. Bermain juga merupakan kegiatan yang dilakukan untuk kesenangan tanpa mempertimbangkan hasil.Di samping itu bermain adalah kegiatan yang tidak mempunyai peraturan yang dibakukan melainkan ditetapkkan oleh para pemain sendiri" (Elizabeth B. Hurlock. 1993:320).
\end{abstract}

Dari pendapat di atas dapat di simpulkan bahwa bermain adalah suatu kegiatan yang melibatkan atau mental seseorang anak (siswa) sehingga, dapat mempengaruhi dalam bidang kehidupan. Terlihat dari kegiatan bermain dapat menyenangkan, menggembirakan, spontan, sukarela, cukup aktif dan mempunyai tujuan-tujuan tertentu. Para ahli psikologi juga mengemukakan beberapa teori tentang bermain yaitu:

1) Teori Herbert Spencer Teorinya bernama teori kelebihan tenaga.la berpendapat bahwa "anak itu bermain, karena dalam arti anak itu tersimpan tenaga yang lebih sehingga harus menyalurkan bagi manusia untuk melepaskan sisa-sisa energi".

2) Teori Lazarus

Teori ini dinamakan teori istirahat.Anak bermain agar "tenaganya pulih kembali misalnya: karena upaya belajar maka anak-anak harus beristirahat untuk bermain-main".

3) Teori Karl Groos

Teorinya bernama teori biologis.Anak-anak bermain karena "harus mempersiapkan diri dengan tenaga dan pikirannya untuk masa depan.Anak bermain untuk melatih organ-organ jasmani dan rohaninya untuk 
Vol. 2, NO. 2, Mei 2017

menghadapi

masa.depan. Menurut

Groos makin tingggi

tingkat hidup seseorang,

maka makin banyak yang

harus

di

persiapkan.Diantara

anak yang satu dengan

yang lain tidak sama, sehingga anak yang satu lebih memerlukan waktu untuk bermain dari pada anak yang lain".

4) Teori Stanley Hall

Teori ini dinamakan teori rekapitulasi artinya

"anak bermain karena mengulang

perkembangan hidup manusia yang berabadabad secara singkat.Menurut Hall memandang permainan berdasarkan teori rekapitulasi yaitu ulangan bentuk-bentuk aktivitas yang dalam perkembangan jenis manusia pernah memegang peranan yang dominan".

5) Teori Karl Bucler Teorinya disebut teori fungsi, "anak-anak bermain harus melatih fungsi-fungsi jiwa raganya untuk mendapatkan kesenangan dengan permainan itu, dan mengalami perkembangan fase maksimalnya".

6) Teri Kohnstam Teori ini dinamakan teori kepribadian.Anak-anak bermain karena "dalam permainan itu mereka berada dalam suasana yang bebas.Selain itu melalui permainan dapat diketahui bagimana ia bergaul, sikapnya terhadap lawan, terhadap kawan, terhadap orang tua dan tata tertib dan sebagainya (Elizabeth B Hurlock. 1993:321)

Berdasarkan teori di atas dapat kita simpulkan bahwa melalui aktivitas bermain dalam semua bidang dapat memupuk perkembangan anak atau siswa-siswa disekolah dasar diantaranya:

a. Pemainan gerak atau fungsi (permainan ini mengutamakan aktivitas gerak yang berisi kegembiraan sambil melakukan berbagai aktivitas gerak).

b. Permainan destruktif (anak bermain dengan menggunakan alat-alat permainan sehingga para peserta permainan menemukan kesenangan).

c. Permainan kontruktif (para pemain membangun menyusun benda-benda seperti balok, batu, dan sebagainya 
Vol. 2, NO. 2, Mei 2017

menjadi suatu bangun yang mempunyai arti).

d. Permainan peran atau ilusi (permainan ini membuat para peserta menjadi seorang yang penting; contoh siti bermain boneka, siti berperan sebagai ibu).

e. Permainan reseptif (permainan ini menggambarkan cerita dari guru atau orang tua siswa atau guru dari sekolah, para peserta dalam hal ini menempatkan dirinya sebagai tokoh seperti: menangis, berlari, meluapkan kegembiraan, bangga, mencapai kemenangan dan sebagainya).

f. Permainan prestasi (dalam permainan ini para peserta berlomba-lomba untuk unjuk kebolehan, baik kelebihan ketangkasan keterampilan dan kekuatan yang dimilikinya).

Permainan kecil sebagai satu rangkaian akivitas fisik akan memiliki banyak manfaat, serta mempunyai fungsi yang baik terhadap perkembangan fisik dan psikis seseorang. Menurut pakar pendidikan Soemitro (1992:6) fungsi bermain dalam pendidikan jasmani diantaranya yaitu:

a. Membina mental

Suasana dalam bermain selalu bebas, tetapi dalam Suasana tersebut setiap individu yang ikut bermain dituntut untuk mengikuti ketentuanketentuan atau permainan itu sendiri. Misalnya seseorang harus tahu dengan haknya sendiri, juga harus belajar menghormati hak individu yang lain, mereka belajar berbuat saling mempercayai diantara kelompoknya. Belajar mengenal kekurangan dirinya jika dibandingkan dengan orang lain, dan mengikuti dengan jujur kelebihan orang lain.

b. Membina fisik

$$
\text { Bergerak yang dilakukan dalam }
$$
bermain tentu saja serta dengan kegembiraan. Suasana gembira ini mempunyai pengaruh terhadap 
Vol. 2, NO. 2, Mei 2017

keluarnya hormon-hormon yang
merangsang pertumbuhan tubuh
seseorang.

c. Membina sosial

Permainan kecil dapat dilakukan dengan satu lawan satu, satu lawan kelompok dan bahkan kelompok lawan kelompok. Permainan kecil terdapat saling memberi dan menerima, anak belajar menyadari kekurangan dirinya, belajar memperlakukan lawan sebagai teman bermain.

Sesuai dengan kutipan di atas, dapat dikemukakan bahwa permainan kecil memiliki banyak dan dalam kehidupan baik bagi orang dewasa maupun anak-anak. Kemudian dalam hal ini permainan kecil bisa dikembangkan dan diterapkan oleh guru pendidikan jasmani kesehatan di sekolah. Karena dapat mempengaruhi kesegaran jasmani, motivasi, pertumbuhan dan perkembangan fisik, perkembangan intelektual, pembentukan kerjasama sosial emosional, prestasi belajar, dan kondisi fisik siswa di sekolah.

Selanjutnya terlihat adanya unsurunsur rasa kebersamaan dan saling menghargai teman dalam kelompok maupun di luar kelompok. Untuk itu permainan kecil sangat baik diberikan dan memacu semangat siswa dalam mengikuti proses pembelajaran pendidikan jasmani kesehatan di sekolah. Siswa yang melakukan kegiatan pembelajaran tidak merasa terpaksa, karena ada unsur bermain dan kegembiraan. Permainan kecil dapat meningkatkan kekompakan antara satu dengan yang lainnya, sehingga terjadi rasa sosial yang tinggi sesama siswa.

Sekaligus dengan bermain dapat mendidik anak belajar sportif, karena anak yang kalah akan mengakui kekalahannya dari teman yang menang. Untuk meningkatkan kesegaran jasmani, motivasi, pertumbuhan dan perkembangan fisik, perkembangan intelektual, pembentukan kerjasama sosial 
Vol. 2, NO. 2, Mei 2017

emosional, prestasi belajar, dan kondisi fisik siswa di sekolah, dapat dilakukan dengan mengembangkan gerak dasar melalui Permainan Kecil Dalam Proses pembelajaran pendidikan jasmani kesehatan. Permainan kecil sebagai aktivitas fisik mengandung beberapa aspek yang perlu diperhatikan, sesuai dengan yang dikemukakan oleh Alimunar (1992: 8):

\section{a. Aspek Motorik}

Melalui permainan kecil yang dilakukan siswa, baik secara individu maupun kelompok saling berjuang untuk mencari kemenangan, dengan bermacam-macam gerakan seperti: berlari, melompat, berguling, dan sebagainya. Kegiatan yang dilakukan siswa dalam bermain, terdapat unsurunsur kecepatan, kekuatan, kelenturan, dan keseimbangan terhadap fisik mereka.

b. Aspek kognitif

Permainan kecil yang diberikan kepada siswa sebagai rangkaian ativitas fisik, akan mengajak siswa turut berfikir dan mengembangkan penalaran serta pendapatnya dalam melakukan permainan kecil sesuai dengan peraturan yang telah ditetapkan.

c. Aspek sosial

Waktu melakukan permainan siswa perlu kerjasama yang baik dalam kelompoknya dan mereka saling membutuhkan, saling berinteraksi dalam bermain, setiap peserta merasakan betapa pentingnya kawan dalam afektif.

d. Aspek afektif

Permainan kecil sangat mudah dilaksanakan dan tidak tergantung pada alat, tempat, dan waktu.Sebagai rangkaian kegiatan fisik permainan kecil dapat meningkatkan perkembangan psikis (perasaan) disamping fisik.

Berdasarkan dari kutipan di atas, dapat dikemukakan bahwa permainan kecil ini memiliki beberapa aspek yang dapat membantu peserta ataupun siswa yang mengikutinya.

Aspek di sini diantaranya yaitu motorik, kognitif, sosial, dan afektif. Kemudian melalui aspek ini jugalah peserta atau pun siswa dapat 
Jurnal Menssana

Vol. 2, NO. 2, Mei 2017

terbantu untuk meningkatkan kesegaran

jasmani, motivasi, pertumbuhan dan

perkembangan fisik, perkembangan

intelektual, pembentukan kerjasama sosial

emosional, prestasi belajar, dan kondisi fisik

siswa di sekolah. Untuk itu dalam pendidikan jasmani dan kesehatan hendaknya guru di sekolah menjadikan kegiatan permainan kecil ini bagian dari proses pembelajaran. 